DOI https://doi.org/10.30970/2078-6999-2019-22-7

\title{
LISTENING TO THE VOICE D'UNE PAROLE: CALL AND RESPONSE IN JEAN-LOUIS CHRÉTIEN'S PHENOMENOLOGY
}

\author{
Andriy Hnativ \\ Faculty of Philosophy \\ Ivan Franko National University of Lviv \\ 1, Universytetska St., Lviv, 79000, Ukraine \\ epifanij@yahoo.com
}

The aim of present essay is mainly to introduce a role for phenomenology in Jean-Louis Chrétien's thought of call (appel) and response/answer (réponse) by examining the various phenomena to the point where Chrétien challenges the boundaries between philosophy, poetry and theology as a result of the re-establishing phenomenological tradition and of appeal to the Dialogues of Plato, as well, to the contemporary philosophical discourse. In treating the multileveled progression toward the goal of mentioned philosopher's cuvres which sense can be altered by contaminatedly accomplished efforts of translations if original French texts are not employed in our research, we wish to interrogate the inner inter-relatedness of Jean-Louis Chrétien's pensée for an analysis of call and response, of their content and structure.

Key words: call, response, beauty, creation, election, voice.

\section{The unheard-of Jean-Louis Chrétien's phenomenological hospitality}

Jean-Louis Chrétien's phenomenology of call and of response constitutes one of the most contemporary attempts to set up a new relation addressing to the thought of Neoplatonism, later Patristics, Medieval thinkers, which opened new ways for XX and XXI centuries of phenomenology to concern the multiple modes of manifesting phenomena. Associated with the «theological turn» in contemporary French phenomenology, Jean-Louis Chrétien is able to find a close approximation to the readings of the major unforgettable figures such as Jacques Derrida, Emmanuel Lévinas, Michel Henry, Jean-Luc Marion. Professor of philosophy at the University of Paris-IV, Jean-Louis Chrétien (born in 1952), he specifies his subtile reflections in books as La Voix nue. Phénoménologie de la promesse (1990), L'inoubliable et l'inespéré (1991), L'appel et la réponse (1992), De la fatigue (1996), Corps à corps: à l'écoute de l'œuvre d'art (1997), L'Arche de la parole (1998), Le Regard de l'amour (2000), Saint Augustin et les actes de parole (2002), Promesses furtives (2004), La joie spacieuse. Essai sur la dilatation (2007), Répondre: Figures de la réponse et de la responsabilité (2007), Conscience et roman I: La conscience au grand jour (2009), Conscience et roman II. La conscience à mi-voix (2011), L'Espace intérieur (2014), Fragilité (2017) [17, p. 569-570].

In the previously mentioned source, namely «La voix nue», Chrétien is describing the notion of 'naked', 'in-visible', 'incorporeally-silent' voice d'Autrui (Other) which «is a response to a prior call» $[4$, p. $12 ; 13$, p. 145]. Furthermore, status quo of «The call and the response» also includes a profoundly elaborated reflection on voice, call, response, listening and touch $[14$, p. 147]. Chrétien's intention is to pay attention to his analysis of tracery (entrelacs) of call and response in the dialogue between subjectivities and words, emphasizing how the existence and the speech are thus subsequently founded on the call of beauty, previously traced election of creation. Focusing on the unheard call and unanswered response we can ask ourselves, to

(C) A. Hnativ, 2019 
what extent can we listen to the call which precedes the response? How and why can response pretend to resonate within the call of voice and simultaneously to witness the voice of call? These questions are central of book «The Call and the Response» and, instead, develop Chrétien's later projects. At the heart of vocational provocation of call, we noteworthy sketching the structure of «The Appeal and the Response» which includes four parts, à savoir, the call and the response, the visible voice, the another voice and finely the corpus and touch. The first part which tonalizes our research is associated with the event of call clarified itself by the inceptive response. In the second part Chrétien captures us into the relation to Paul Claudel's remarkable title «The Eye Listens» [10] in which speech «keeps watch» and ear «re-gards», rendering them open to revelation of «other voice» [5, p. 33]. The other voice in third part turns to Socrates' doemon and St. Augustine's verbum cordis that take the forms of a divine inner voice. Maintaining the difference between Gewissen (conscience) and Bewusstsein (consciousness) in Kant's way of bringing together the voices of my and other's consciences in order to evaluate the boundaries among them [4, p. 89-93], Chrétien finally makes reference to the infans (from infari, speechless being) and exerts a claim of St. Augustine's Confessions (397 AD) «Non enim eram infans, qui non farer, sed iam puer loquens eram» (I was non longer an infant who does not speak, but a speaking child). Any attempt to penetrate the call of infancy contributes to excess of voice that has not yet been said or written. To be capable of existence, of speech, of thinking, Chrétien invites us in fourth part to challenge the relationship of voice and touch. From these points forward, consequently, we limit our reflection within the first part of «The call and the response» where «the call shows itself in the response» [21, p. 282].

It's clear that Chrétien's approach to call reconsiders at first shortly of the call of Seyn (Beyng, Being) and the call of the face of Other in which both Heidegger and Lévinas try to confront the question for exceeding metaphysics. In Heidegger's notion of call, we read the way in which the relationship between call and response accomplishes a correspondence among the call of souci (care) and the call of Dasein [16, § 57]. The central question of Heidegger's ontology is shaped by reflection on being by dividing word and thinking not in terms of what is their $\dot{\alpha} \rho \chi \eta^{\prime}$ (origin), but in terms of responding to the call of «beyng» (Contributions, section 255). Beyng, by its soundless voice (lautlose Stimme), articulates itself between the desire to respond and the listening to the call of echo of beyng [15, p. 283]. The substitution of call-response-model for speech as correspondence (Entsprechen) in On the Way to Language causes a «twofold way, receiving and replying» and finally, «the call of the silent voice is heard only in the answer, the provocation is heard only in my invocation» $[5$, p. 29-30]. Consequently, heideggerian correspondence in front of the infinity of a call does not correspond to the impossibility of being as a co-answer to the call of infinite. Excess of the call (Anspruch, Anruf, Ruf) [16, § 56, p. 362-364] not only destructurizes the meaning of Heidegger's notions of «call» (der Angesprochene), «responsibility», «responsiveness» «voice of friend», conscience and Dasein (als Ruf der Sorge) $[11$, p. $348-349 ; 16, \S 57$, p. $364-371]$, but insists that «the call is confirmed by the response to the call. The call is given and donated; it is not given silently to anyone except the answer. The response responds to the call and it is smoothed out before the call» [11, p. 351]. Primacy of the call becomes the condition of the possibility of response, and that is why it is impossible to response to respond early to the call because «if the call establishes the possibility of response, then it is impossible for the response to correspond to the call» [12, p. 187]. Therefore, if Heidegger's «soundless voice of beyng» is «speech itself, the address of language that we receive at birth and to which we respond, then for Chrétien the call comes from God» [3, p. 170; 18, p. 11-19]. It seems rather evident for Chrétien, that «the call is a call from the infinite, sent into infinity itself (...) Nothing can correspond to the infinite (...) Insofar as the call comes from the infinite, 
we are, as the poet Lorand Gaspar expresses it, forever in it as 'the name which is pronounced through a vacancy of hearing'. Such vacancy of hearing mark all correspondence as impossible» [5, p. 31].

Contrary to heideggerian call of beyng, Emmanuel Lévinas inscribes the call within faceto-face relation, precisely, because «l'appel s'entend dans la réponse» (the call is understood in the response) [18, p. 20]. The call, blessed or wounded by voice of Other, can, from one side, precede my response, and from another side - it wakes up my affection of being in front of hospitality, traced by «interpellation» of Other's otherness. The point is made clearly in Totality and Infinity or Otherwise than Being or Beyond Essence where the excess of call asymmetrically leads me to admit that I am in retard (delay) to respond me voici (here I am). This is why «our responses are always deficient, always incomplete; the call always exceeds them immeasurably. And yet this very vulnerability and insufficiency is what enables and calls forth the response. This inexhaustibility of the call and deficiency of our response, in fact, is what enables us to live, to dwell, and to create: all of our lives become a response to the call. Chrétien often thinks of the call in a Lévinasian sense. It is the calling to which we must respond me voici (here I am): «The call is heard only in the response» [5, p. 30; 14, p. 150]. While Lévinas wants to reverse intentionality to speak of call as subject's 'becoming object' [25, p. 115], Jean-Luc Marion finds the Lévinasian call in the Other's face obviously exhausted when he, for example, concludes as follows: «as face, he faces me, imposes on me to face up to him as he for whom I must respond. But if I must respond for him, I must, I must also respond to him. I have therefore received (and suffered) a call [un appel]. The face makes an appeal [un appel]; it therefore calls me forth as gifted» [20, p. 368; 21, p. 267]. In Marion's view the face becomes an adonné (gifted), who «receives himself as the call that he receives is given - undeniably» [21, p. 267-271].

2. The first call vis-à-vis of surcroît/surplus (excess) of response relating to the primordial call of beauty

Beauty is in all circumstances immediate inauguration of first call to respond. But how is it possible to think of «this excess of the encounter with things, others, world and God?» Besides of these «encounters» which «require, most imperatively, our response, and yet seem at the same time to prohibit it» [14, p. 149; 7, p. 121], the basic idea of Jean-Louis Chrétien permits the beauty does not say le dernier ADIEU [6, p. 77-110]. The beauty witnesses the old Platonic tradition that there is not any diametrically destroyed abyss of response from a call. There is not a clivage (cleavage) running through Plato's Cratyle privileging its etymological justification by manifestation of beauty phenomena. For both Plato and Chrétien, the word «beautiful» re-establishes the origin of the word kalon [5, p. 7], and «comes from a call, kalein, which continues to call through and in it.» [5, p. 7]. To identify phenomenologically Plato's «origin of language», nevertheless the author of dialogues appropriates to the «ta kala» (beautiful things) the capacitas 'nominis' of naming 'that which in speech calls» [5, p. 7]. The perplexity of Greek language is significant according to Chrétien, since «kalein (to call) possesses the double meaning: «at once to call out, hail, summon, and to bestow a name, to name» $[5, \mathrm{p}$. 7]. The movement toward beauty enters the space of relational excess of call accepting to be acknowledged by ta kala (beauties) which to kaloun (call) to respond. In other words, phenomenality of call refers beauty to the origin of the world, of called God and understanding of human being. Chrétien highlights that «l'événement $d u$ beau est que dans le visible retentisse un appel de l'origine, appellant à l'origine» (The event of the beautiful lies in the fact that the origin calls out audibly in the visible, calling us back to the origin) [4, p. 19-20; 5, p. 9]. The inexhaustibility of beauty calls us to amplify and extend the authenticity of visibility and audibility of things which «speak in the form of a call» [13, p. 207]. The «called» world brings into the clarity of visible light, which, has 
a voice. As evident here again Chrétien refers to the proximity of all things and speech that keep us to close our throat of uncovering beauty that is manifestation of praise and prayer. The French thinker finds in St. Augustine's inspirations another sense for beauty that sets the author of Confessions apart from Plato. While Plato consistently characterizes beauty as strength of call, St. Augustine celebrates beauty as response of love, according «vocem suam, id est speciem suam» [4, p. 47-48; 6, p. 90-92, 100]. For St. Augustine, what is revealed is «the visible voice, beauty which is visible only in the regard which listens to and interrogates» [4, p. 47-48]. While the visible beauty appears to indicate a voice of things, nevertheless this «beauty, we come to see, defies any tidy dichotomy between the seen and the heard. We hear the voice of things through their visible brilliance; the light that illumines them is what brings them into a presence that lets their radiance strike and stir us. In being shocked by their beauty, they wound us, which is why they move us to speak. Beauty, then, is not mute. For in first speaking to us, it rouses our own voice to action» [13, p. 207-208]. Said in different way, speech becomes the ark of things and «things themselves have their own voice - the voice of beauty» [13, p. 215]. Chrétien underlines that «the appearance of beauty does not take place, it makes space. It does not occur in a pre-constituted place from which it derives its condition of possibility, as if it were coming out on to a stage, in a decor and under a lighting that were there before it. By taking place, it makes space: in other words, it causes this place, here, to arise in all its jubilant and heartrending exclamation. The here opened up by beauty cannot be found on any map, any more than flashes of lightning flicker in the margins» [6, p. 79-80]. The encounter of beauty in terms of 'not found' in present supposes the telling phrase: «nothing is lost» of memory which «is saved forever» and «always accessible» $[13$, p. 221]. No doubt creative power of unforgettable as well, means immemorial of wound which «opens up within us, turns us away from lingering in regret, and point us toward the future in hope» against all hope, because there is another dimension which is summarized in «unhopedfor» for a new call [13, p. 223-224]. The beauty as response of call and call of response touches on to its relation to «unhoped-for» and «unheard-of» of beauty. Chrétien thinks that «what makes the beauty $(. .$.$) is nothing other than an excess of beauty itself» [6, p .88]$. This is possible because an excess of eternal beauty exceeds a mortality of beauty where the spoiled pseudo-beauty, by contrast of pride, dies by «its self-sufficiency, its autarchy, everything by which it might become and idol by ceasing to be an event and an advent». He attempts to call beauty as «a way (voie) only when it is a voice (voix), then to see it is to hear it and to reply to it by giving and showing oneself» [6, p. 109-110].

\section{Towards a «phenomenology of response»}

The late night of response can misguide us to vigilate the beautiful dawn of call's arrival 'in-between-ness' (au-mi-lieu) of fresh dew's surprise because call's morning of sun dries all the traces of called voice of responsal. The poetry of night and the delay of «the Responsal» [21, p. 287] challenge our capacity to listen to the «voice (which) is a response to a prior call» $[14$, p. 145]. The «a posteriori of the response» always remains a kind of phenomenalization of call because it «states what the call continually recalled to it» [21, p. 287]. Chrétien emphasizes resounding Dasein of respose in a primordial call which precedes it because «call is heard only in the response» $[4$, p. $30 ; 26$, p. 160]. Chrétien repeatedly points out that «we hear the call only in the answer, in a voice that has been altered by it, which utters the very alteration that gives it to itself as not belonging to itself, and which endures its own unsubstitutable disinheritance. Alteration does not coincide with either possession or substitution. The space of response is opened only by the difference between speaking of oneself and speaking oneself. There can only be a call and a response if the two are no longer conceived as identical and if the fact that we do not speak of ourselves, out of ourselves, actually gives us a voice rather than condemn 
us to silence or to a simulation of speech» [4, p. 27]. Chrétien's call is interpreted as translation which «does not refer back to an original language given before it and outside of it. The original is given only in the translation itself» [2, p. 213]. In fact, for Chrétien «this translation is the very process of our alteration by what strikes us, the movement in which the distinction between appeal and response is erased» 77, p. 123]. In a reflection on translation of call is recall and call of untranslatability as a response to invisible voice. Yet at the same time, it is also true that response envisions itself as translation [24, p. 753]. To become a response through responding to a call, answer maintains the possibility of its own being [9, p. 30]. The response discovers its own responsiveness and responsibility not merely exploiting a parallel between the deficiency of finality and that of finitude. Just as the penultimate self of call, the response is constituted to the point of being involved in a war and play of its phenomenality [9, p. 30]. Thus, assessments of what is answered relates for Marion's "«delay of the responsal» which 'attests «the irreparable excess» of the call over and above every response, no response ever co-responding to the call condemning the human to an «originary difference with itself as an I, therefore [to] inauthenticity» [21, p. 270; 19, p. 109]. While 'inauthentic and improper' "II», as response, can never verify the origin of myself because «I» am not there before my own origin, which has two consequences: my response never measures up to the events that make me who $\langle I\rangle$ am, and the call that makes me myself remains of «indeterminate origin» [21, p. 268; 19, p. 109]. Accepting the aporia, Marion concludes that finally «I» as the «responsal complete the call and simultaneously delays the call», but this «delay attests a double property of the call. First: its irreparable excess over and above all possible responsal and the responsal wearies of showing what the call never grows weary of giving. Next: its fait accompli» [21, p. 269].

These various aspects of Marion's explications of «delay of Responsal» significantly preview terminology in Chrétien's work on «Répondre. Figures de la réponse et de la responsibilité » [9]. Chrétien concludes in last lecture of «Répondre. Figures de la réponse et de la responsabilité» that «Le Répondant, plus fort que nos questions et que nos crimes» (The Respondent stronger than our questions and our offenses « [9, p. 203-238]. Chrétien challenges the primacy of call allowing us to enter into the relation of response and responsibility. As the juxtaposition of question-response and call-response, Chrétien's thinking is guided by an original infinity of second option after showing that the questions formulated by me «are always a kind of response to a phenomenon «I» have already encountered before it gives rise to question: «Only the response to an appeal opens the possibility for true questioning» $[9$, p. $6 ; 14$, p. 151]. Chrétien perfectly defines the response - according C.M. Gschwandtner - in its relatedness with responsibility, because «it is only the response taken up in responsibility that makes visible the call. This is true even of the call of the divine appeal: «I only hear God's appeal through the response of faith, of revolt, or of confusion» [9, p. 15]. Again, response is a bodily experience and a vulnerable one due to the disproportion between call and response» [14, p. 151].

\section{Conclusion}

The relationship between call and response in Jean-Louis Chrétien's phenomenology was the object of our research. Saying otherwise, we can preliminary describe his philosophy «as that of a hospitality to the voice or to the call and to the response. Both call and response resonate in the voice» $[14$, p. 144, 146]. Far from cutting us off from Plato's notion of beauty, Chrétien makes many references to an aesthetic of later Patristics and Medieval thinkers, which «could aptly be characterized as a 'theology of gloriae [that] remains a theology of excessus', to use Hans Urs von Balthasar's description» [1, p. 293]. According Chrétien's elaboration of a phenomenology of call-response-structure, his book «L'Appel et la Réponse» has shown us that the excess of the appeal over our response, in so far as it crosses this response through and through, is what gives it its stature and weight» [7, p. 125]. 


\section{References:}

1. Ballan J. Between Call and Voice: The Antiphonal Thought of Jean-Louis Chrétien / Words of life. New theological turns in French Phenomenology / ed. by B. E. Benson-N. Wirzba; New York: Fordham University Press, 2010. - P. 196-207.

2. Benson B.E. Chrétien on the Call that wounds // Words of life. New theological turns in French Phenomenology / ed. by B. E. Benson-N. Wirzba; - New York: Fordham University Press, 2010. - P. 208-221.

3. Boer R. The pure giveness of the call/event: between Alain Badiou and Jean-Louis Chrétien/ R. Boer // Colloquium. - 2012. № 44/2. - P. 163-176.

4. Chrétien J.-L. L'appel et la réponse / J.-L. Chrétien. - Paris : Éd. De Minuit, 1992. - 155 p.

5. Chrétien J.-L. The Call and the Response / J.-L. Chrétien; [tr. A. Davenport]. - New York: Fordham University Press, 2004. - 144 p.

6. Chrétien J.-L. The Ark of speech / J.-L. Chrétien; [tr. A. Brown]. - London and New York: Routledge, 1998. - $170 \mathrm{p}$.

7. Chrétien J.-L. The Unforgettable and the Unhoped For / J.-L. Chrétien; [tr. J. Bloechl]. - New York: Fordham University Press, 2002. - 135 p.

8. Chrétien J.-L. Saint Augustin et les actes de la parole / J.-L. Chrétien. - Paris : PUF, 2002. - P. 211-222.

9. Chrétien J.-L. Répondre. Figures de la réponse et de la responsabilité / J.-L. Chrétien. Paris : PUF, 2007. - $256 \mathrm{p}$.

10. Claudel P. Cinq grandes odes. Euvres poétiques / P. Claudel. - Paris : Éd. Petit, 1967.

11. Courtine J.-F. Heidegger et la phénoménologie / J.-F. Courtine. - Paris : Vrin, 1990. - P. 327-353.

12. Davis J. The Call of Grace: Henri de Lubac, Jean-Louis Chrétien, and the Theological Conditions of Christian Radical Phenomenology // Words of life. New theological turns in French Phenomenology / ed. by B. E. Benson-N. Wirzba; - New York: Fordham University Press, 2010. - P. 181-195.

13. DeLay S. Phenomenology in France: A Philosophical and Theological Introduction / S. DeLay. - London: Routledge, 2018. - P. 200-246.

14. Gschwandtner C. M. Postmodern Apologetics? Arguments for God in contemporary philosophy/ C. M. Gschwandtner. - New York: Fordham University Press, 2013. - P. 143-162.

15. Heidegger M. Das Ereignis / M. Heidegger. - Frankfurt am Main: Vittorio Klostermann, 2009. GA 71 - P. 283-284.

16. Heidegger M. Sein und Zeit / M. Heidegger; Tübingen: Max Niemeyer Verlag, 1976-583 p.

17. Gondek H.-D. - Tengelyi L. Neue Phänomenologie in Frankreich / H.-D. GondekL. Tengelyi; - Berlin: Suhrkamp Verlag, 2011. - 368-580 p.

18. Gramont de J. L'aventure de la parole selon Jean-Louis Chrétien / J. de Gramont // Comprendre. - 2017. - № 19/2 . - P. 9-30.

19. Kosky J. L. The Human in question: Augustinian dimensions in Jean-Luc Marion // Words of life. New theological turns in French Phenomenology / ed. by B. E. Benson-N. Wirzba. New York: Fordham University Press, 2010. - P. 103-119.

20. Marion J.-L. Étant donné. Essai d'une phénoménologie de la donatin / J.-L. Marion. - Paris: Quadrige/PUF, 2005. - $452 \mathrm{p}$.

21. Marion J.-L. Being Given: Toward a Phenomenology of Givenness / J.-L. Marion; [tr. J. L. Kosky]. - Stanford: Stanford University Press, 2002. - 385 p.

22. Peruzzotti F. Lo scritto e il suo lettore. In ascolto di Jean-Louis Chrétien, Martin Heidegger, Jean-Luc Mation / F. Peruzzotti. - Milano-Udine: Mimesis, 2015. - P. 65-109.

23. Thirion B. L'appel dans la pensée de Jean-Louis Chrétien. Contexte et introduction / B. Thirion. - Paris : L'Hartmattan, 2002. -238 p.

24. Thirion B. Par une blessure engendré... Introduction à la notion d'appel chez Jean-Louis Chrétien / B. Thirion // Revue Philosophique de Louvain. - 2002. № 100/4. - P. 742-761. 
25. Thomas-Fogiel I. The call in the thought of Lévinas, Marion and Chrétien: Description of Phenomenon or Deconstruction of a Tradition? / I. Thomas-Fogiel // Aisthesis. Pratiche, linguaggi e saperi dell'estetico. - 2011. - №4/2. - P. 111-135.

26. Simmons J. A. - Benson B. E. The New Phenomenology. A Philosophical Introduction / J.A.Simmons-B.E.Benson.-London-New Delhi-New York-Sydney:BloomsburyAcademic, 2013. $-285 \mathrm{p}$.

\title{
ВСЛУХАЮЧИСЬ У ГОЛОС СЛОВА: ПОКЛИК І ВІДПОВІДЬ У ФЕНОМЕНОЛОГІЇ ЖАНА-ЛУЇ КРЕТЬЕНА
}

\author{
Андрій Гнатів \\ Львівський національний університет ім. І. Франка \\ Філософський факультет, кафедра філософії \\ вул. Університетська 1, 79000, Львів, Україна \\ e-mail:epifanij@yahoo.com
}

Дана стаття ознайомлює українського читача з тематичним доробком сучасного французького філософа Жана-Луї Кретьєна (нар. 1952), розкриваючи співвідношення поклику та відповіді. У творі «Поклик та відповідь» Жан-Луї Кретьєн пише, що «поклик, кличучи мене, не залишає мене неушкодженим», тому що «відкриває у мені простір слухання» та розбиває в мені моє попереднє відчуття «бути покликаним». Незважаючи на будь-який спротив не слухати голос поклику та ігнорувати подію відповіді на поклик, суб'єкт, як покликаний покликом (l'appelant de l'appel), не в стані охопити «непослідовність» становлення сутності «інтимного» поклику своїм очікуванням. 3 огляду на первинність поклику, який стає умовою можливості відповіді, неможливо самій відповіді відповідати поклику, оскільки «розмова розпочинається 3 неможливості відповідати (correspondre) на запрошення говорити». У даний спосіб Жан-Луї Кретьєн, Жан-Люк Маріон, Еммануїл Левінас і, протилежно Гайдегтер, відводять роль поклику, позбавленого метафізичного початку мови та відповідального за «повалення інтенціональності». Відмінювання «я», як «мене» в родовому (Гайдегтер), «мене» у знахідному (Левінас), «мені» у давальному відмінках (Маріон) визначають поняття «поклику», як буття перед обличчям іншого, відданого (adonné).

Натомість за визначенням Жана-Луї Кретьєна, поклик (до)-прекрасного, Божий поклик, поклик до відповідальності, поклик тіла впроваджують категорію «відповіді», як своєрідного дару на голос поклику. Привілей відповіді відповідати на поклик (appel), розглядаються як пригадка (rappel) першого поклику оновлювати людську здатність слухати та відповідати на поклик «прекрасного». Краса, прекрасне, стають першим наміром зустрічі суб'єкта зі світом, який не тільки існує у ньому, але також і надає речам імена. Інтерпретуючи платонівський діалог «Кратил» (416 Б-Д) Жан-Луї Кретьєн простежує значення грецького слова «краси» (ta kala), яка кличе (to kaloun). Поклик закликає до краси, як виклик на відкритість та закритість перед «пре-красним», тому що поклик (kalein) віднаходить свою конотацію в (kalon). Почута краса, як прекрасне поклику, зранює імперативним надміром відповідаючого відповіддю на поклик, адже «від цієї рани народжується радість пісні» творіння. Кретьєн пише : «поява прекрасного не займає місця (place), вона (краса) породжує місце (lieu). Прекрасне не твориться в наперед визначеному просторі, як передумові умови своєї можливості, як начебто прекрасне увійшло б на сцену, в декорі, під попередньо встановленим освітленням (...). Прекрасне дає початок, змушує людину піднятися під радісний і несамовитий вигук. Відкрите «ось-тут» прекрасного не з'являється на жодному кадастрі, уподібнюючись блискавкам, які не з'являються». У намаганні зрозуміти нескінченність поклику та кінцевість відповіді, Жан-Луї Кретьєн резюмує миттєвість цього відношення описом неуособленого діалогу Поля Клоделя з музою Ерато: «Ерато, ти споглядаєш на мене, і я відчитую у твоїх очах рішення! Я читаю відповідь, читаю питання у твоїх очах. Відповідь і питання у твоїх очах!»

Ключові слова: поклик, відповідь, краса, творіння, вибір, голос. 